\title{
Groundedness as Risk: Adaptive Strategies for Ground Failures in Seattle
}

\author{
Arthur Tai-Ming Leung
}

\begin{abstract}
Groundedness" implies stability and permanence, but our reliance on the presumed fixity of the earth under our feet has led us to lose sight of its dynamism. From macro tectonic readjustments to micro sediment transport, these natural processes are part of an adaptive cycle that oscillates between stasis and destruction. Urban development, predisposed to Engineering Resilience, has exacerbated disasters by attempting to fix and control ground without considering the recombinant and indeterminate systems of Ecosystem Resilience. Seattle is the largest city in a region due for its "Next Big One" - a megathrust earthquake in the Cascadia Subduction Zone. This high-magnitude perturbation would occur in an urban context already sensitive to geologic risks. A history of land manipulations has affected Seattle's ground equilibrium, making it more susceptible to natural disasters. The urgency of the impending risks has inspired adaptive design that foregrounds action as a means of developing a disposition. A catalogue of strategies is applied to a masterplan that balances "sediment" as a resource that builds resilience to ground hazards and promotes ecosystem health.
\end{abstract}

Keywords: adaptive strategies, ground failures, panarchy, Seattle, sediment

Peering through a riparian grove, a group of red gantry cranes on the opposite bank of the Duwamish River stretch their necks to the sky as they await their shipments of containers. Clouds, fed by exhaust from factory chimneys, loiter over the industrial lands of Seattle. Murky, sediment-laden 
waters slow before emptying into Elliott Bay. The tranquility of this working landscape disguises the city's looming threat - the "Next Big One," an overdue megathrust earthquake in the Cascadia Subduction Zone. This high-magnitude, low-probability earthquake will occur in an urban context already sensitive to ground failures, such as landslides, liquefaction, and sea level rise (Fig. 1). With the growth of the city, Seattle has also grown further from its equilibrium state, making it more susceptible to natural disasters. This project is a framework for disaster contingency planning, organized into four parts: Visualizing Cycles, Calculating a Sediment Budget, Cataloguing Adaptive Strategies, and Masterplanning Scenarios. Using the concept of "panarchy" to understand complex systems, it contributes to the advancement of this theory from heuristic to transformational practice through design research. Investigations that begin within an expanded scope eventually narrow, with granularity, to solve a tectonic problem. The project proposes the use of adaptive strategies over the next 100 years to conserve "sediment" ${ }^{1}$ as a resource that builds resilience to ground hazards and promotes ecosystem health.

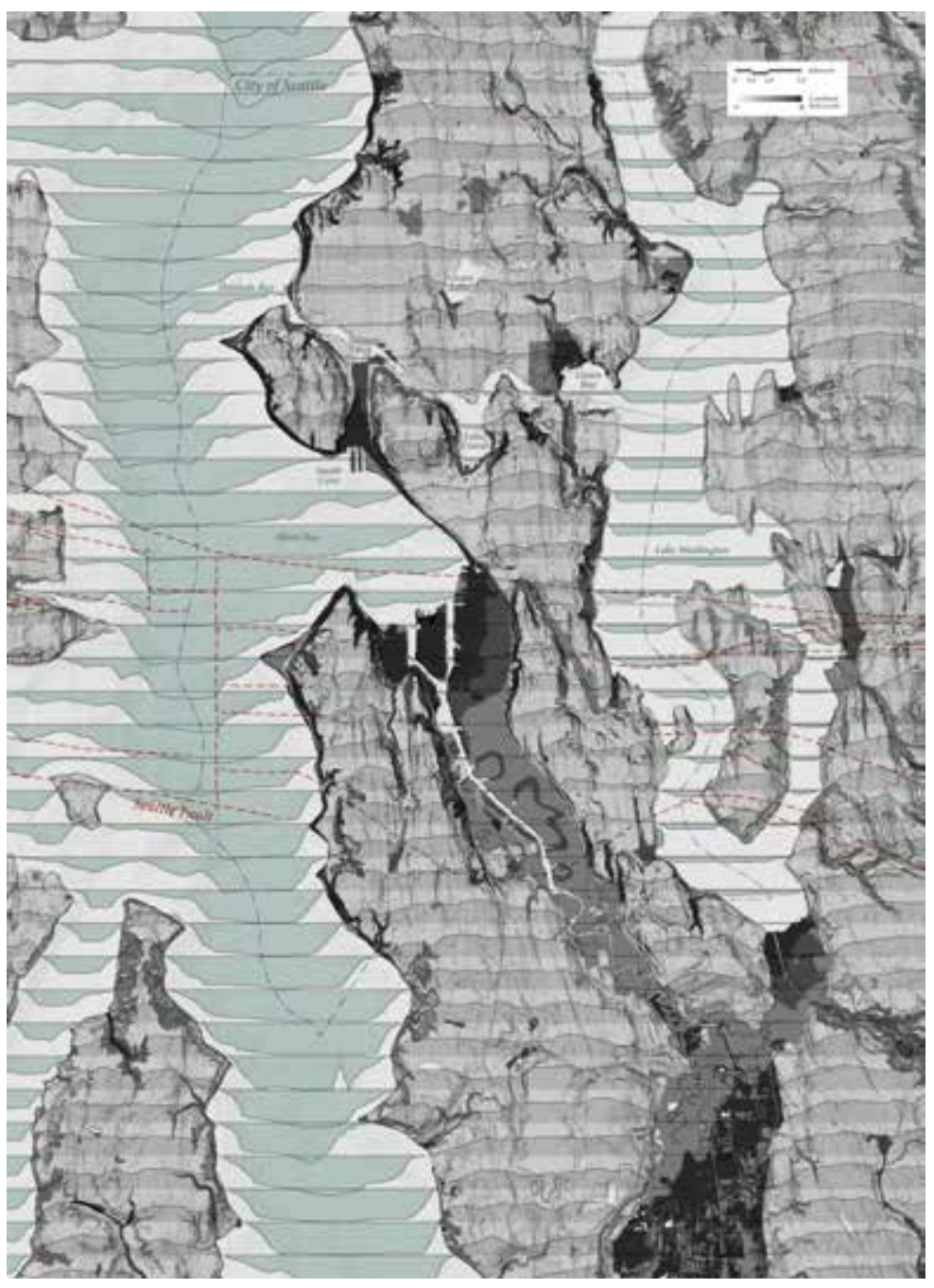

Figure 1.

Risk zones of combined ground failures in Seattle. 


\section{RISKS: FROM PLATES TO PARTICLES}

Since the region's last recorded megathrust earthquake in 1700, tectonic stress has been building up again between the Juan de Fuca Plate and the North American Plate. Evidence from deep-sea deposits, tree fossils, and sedimentation patterns indicates substantive compressive stress release from the Cascadia Subduction Zone every 500 to 600 years. $^{2}$ Although recurrence rates are debated amongst scientists, earthquakes are inevitable in Seattle due to its position at the convergence of multiple tectonic zones. Sharing the same plate interactions as the Cascadia Subduction Zone, deep-focus earthquakes from the Benioff Zone occur directly below the populous Puget Sound. Potentially more catastrophic are shallow, crustal earthquakes from the Seattle Fault, which traverses the Duwamish Industrial Lands. Situated in an urban context, the expected degree of damage would be similar to the 1994 Northridge earthquake or the 1995 Kobe earthquake.

\section{Gravitational Instabilities}

Other ground failures can be activated by earthquakes, such as landslides on weakened slopes. This correlation may not be immediately discernible as mass movements can be delayed days after the initial seismic event. A 2013 report on seismically-induced landsliding in Seattle found that 8,500 buildings fall within landslide debris run-out zones. ${ }^{3}$ They include hillside "view properties," ${ }^{4}$ which are inherently at risk of landslides as they strip slopes of vegetation, alter soil compactness and permeability, and manipulate stormwater conveyance. In all, $84 \%$ of inventoried landslides in Seattle involved some human intervention, ${ }^{5}$ such as interrupting slopes with retaining walls, steepening slopes by excavating and filling, introducing impervious surfaces, and diverting and detaining water in weak zones.

Prolonged rainfall can increase pore water pressures and lower the effective stress in a soil matrix. The landsliding report also compared the effects of water infiltration on shallow landslides and found that dry soil conditions produced 4,977 landslides, while saturated soil conditions produced as many as 30,699 landslides. ${ }^{6}$ Geologic composition factors into mass movement as water conductivity changes with soil strata. It is common, in Seattle, to find highly permeable deposits (e.g. Vashon Till, Advance Outwash, and Esperance Sand) sitting atop a denser shelf of compacted soils (e.g. Lawton Clay and Olympic Beds) or bedrock, forming an aquiclude on which water accumulates and gushes out at this interface. Surface runoff erosion after heavy winter rainstorms frequently bury railroads running along the toes of bluffs, a result of early parochial land use planning. This part of a slope's anatomy is also subject to undercutting by wave action, which will intensify with the increase in future storm surges. 


\section{Lateral Vulnerabilities}

Similarly, soil permeability and proximity to the water table are factors that lead to soil liquefaction, the reduction of interparticle shear strength whereby solid ground turns into quicksand. Differential settlement of dissolved ground risks damaging infrastructure, rupturing buried water and sewer lines, and interfering with post-disaster firefighting and rescue. Liquefaction-prone soils are usually young deposits that lack sufficient compaction due to rapid deposition, typified by sediments found in the Duwamish River floodplain. This coseismic risk is further compounded on artificial land, subject to non-seismically induced subsidence. Uneven pavement and cracks on buildings in historic neighbourhoods built on reclaimed salt marshes are owed to buried, decomposing organics. The voids this rotting refuse has opened in the ground explain the complaints of basement flooding as groundwater and tidal waters fill these underground pockets.

Even without the subterranean porosity, the rising water datum is expected to displace coastal land uses. Sea levels vary locally based on such factors as wind-driven ocean heights, vertical land movement, local tectonics, the compaction of sediments, the extraction of water or hydrocarbons from subsurface reservoirs, or rates of fluid recharge. ${ }^{7}$ Storm surges are expected be more frequent in Oregon and Washington as the North Pacific storm track migrates northward over the next century. This consequently magnifies the impacts of El Niño in the Pacific Northwest. Despite predictions of glacial rebound causing uplift in Washington, some inland locations (including Seattle) are expected to subside due to irregularities in the deformation of tectonic plates and development-related land compaction. ${ }^{8}$ Large volumes of fluvial sediment normally supply materials for land accretion, which is necessary for coastal replenishment and serves to mitigate sea level rise. However, this sediment accumulation has been regulated by damming, interrupted by coastal development, and diverted by regular maintenance dredging.

\section{RETRACING SEATTLE'S GROUND}

Some 24 million cu. yd. [18,3 million $\mathrm{m}^{3}$ ] of sediment from the early regrades and channelization of the Duwamish River were used to fill tidal flats and expand the city. ${ }^{9}$ The artificial land created on the poorlyconsolidated sedimentary basin of the river has become the Duwamish Corridor: home to Seattle's main industrial district, the Port of Seattle, King County International Airport, and the Boeing headquarters. The growth of the city on this vulnerable land has affected the equilibrium state of Seattle's ground, making it even more susceptible to natural disasters. 


\section{Regrading Ground}

Investors believed the new frontier was destined for greatness, inspiring the designation of the "Seven Hills of Seattle" as an allusion to the "Seven Hills of Rome." Ironically though, to achieve the same success as Rome, some of these proverbial hills had to be sacrificed. Seattle's land was originally platted simply to sell property, without any regard for accessibility. Expanding the city across the irregular terrain soon proved difficult, and its many hills were seen as obstacles to Seattle's path to progress. ${ }^{10}$ Engineer Reginald $\mathrm{H}$. Thomson proposed regrading the land, making it more navigable.

The clashing street grids reflect the topographical evolution: the first streets were oriented along the diagonal coast, then superimposed with a cardinal grid after the hills were flattened. The new street grades were determined by the technology available - the number of horses required to pull a load up a hill. A cost per load was assigned to each gradient, and pavement was selected according to what would provide the best footing. A uniform gradient of $5 \%$ was established based on these parameters. ${ }^{11}$ Untouched slopes can easily be identified as those exceeding this standard. Had the regrades happened after the introduction of mass-produced motor vehicles, these machines would have changed the shape of Seattle.

An ordinance that passed in 1897 initiated the regrade of Denny Hill. Pressurized hoses first washed $110,700 \mathrm{cu}$. yd. [84.636 $\mathrm{m}^{3}$ ] of dirt into Elliott Bay; ${ }^{12}$ then supplemented with steam-powered shovels, another 600,000 cu. yd. [458.733 $\mathrm{m}^{3}$ ] were removed. ${ }^{13}$ This hydraulic sluicing technology, borrowed from gold-mining operations, turned out to be highly effective in a city composed of soft glacial deposits. The Denny Hill Regrade was briefly interrupted by a request from the Rainier Heights Improvement Club to burrow a tunnel through the Jackson Street hill. Engineer Reginald H. Thomas realized it would be cheaper to cut 29 blocks and fill 27, thus resulting in the largest single regrade in Seattle in terms of surface area. ${ }^{14}$ Some 3.35 million cu. yd. [2,56 million $\left.\mathrm{m}^{3}\right]$ of dirt were displaced, effectively decapitating $85 \mathrm{ft}$. [26 m] from the Jackson Street hill. Not yet satisfied with the result, Thomas continued to level the adjacent Dearborn Street hill. In all, $108 \mathrm{ft}$. [33 m] was gouged into the ridge connecting Capitol Hill, First Hill, and Beacon Hill, removing 1.6 million cu. yd. [1,2 million $\mathrm{m}^{3}$ ] of dirt. ${ }^{15}$ The spoils from Jackson Street and Dearborn Street had thus created 85 acres [34,4 ha] of land in the tidal flats. ${ }^{16}$ After completing these two regrades, attention was redirected back to Denny Hill. An extensive conveyor belt system was introduced to carry excavated materials to the shores of Elliott Bay, to then be loaded onto self-dumping wooden scows and disposed of in open waters. By 1930, 4.35 million cu.yd. [3,3 million $\left.\mathrm{m}^{3}\right]$ of materials were removed from Denny Hill, with the deepest cut being $107 \mathrm{ft}$. [32,6 m] at 4th Avenue (Fig. 2). ${ }^{17}$ 
The regrades had flattened dangerously steep slopes, but in doing so, another problem was introduced - the displaced sediment had haphazardly filled and buried the Duwamish estuary.

\section{Retooling ${ }^{18}$ Ground}

Aside from topography, the early growth of Seattle was also dictated by coal extraction and logging. Railroad companies vertically integrated these industries with their own to exploit their monopoly over the entire supply chain. They controlled the fate of the Pacific Northwest at that time, by providing access into uncharted territories to tap resources while buying up land to curate expansion along the way. With intense competition amongst cities to attract railroad companies, the City of Seattle was quick to endorse the Seattle and Walla Walla Railroad and Transportation Company, granting "all the tide-flats south of King Street, in, under, around and about Elliott Bay, from extreme high tide to extreme low tide and to deep water." 19 The railroad company now owned an ambiguous yet thick liminal boundary of land and water.

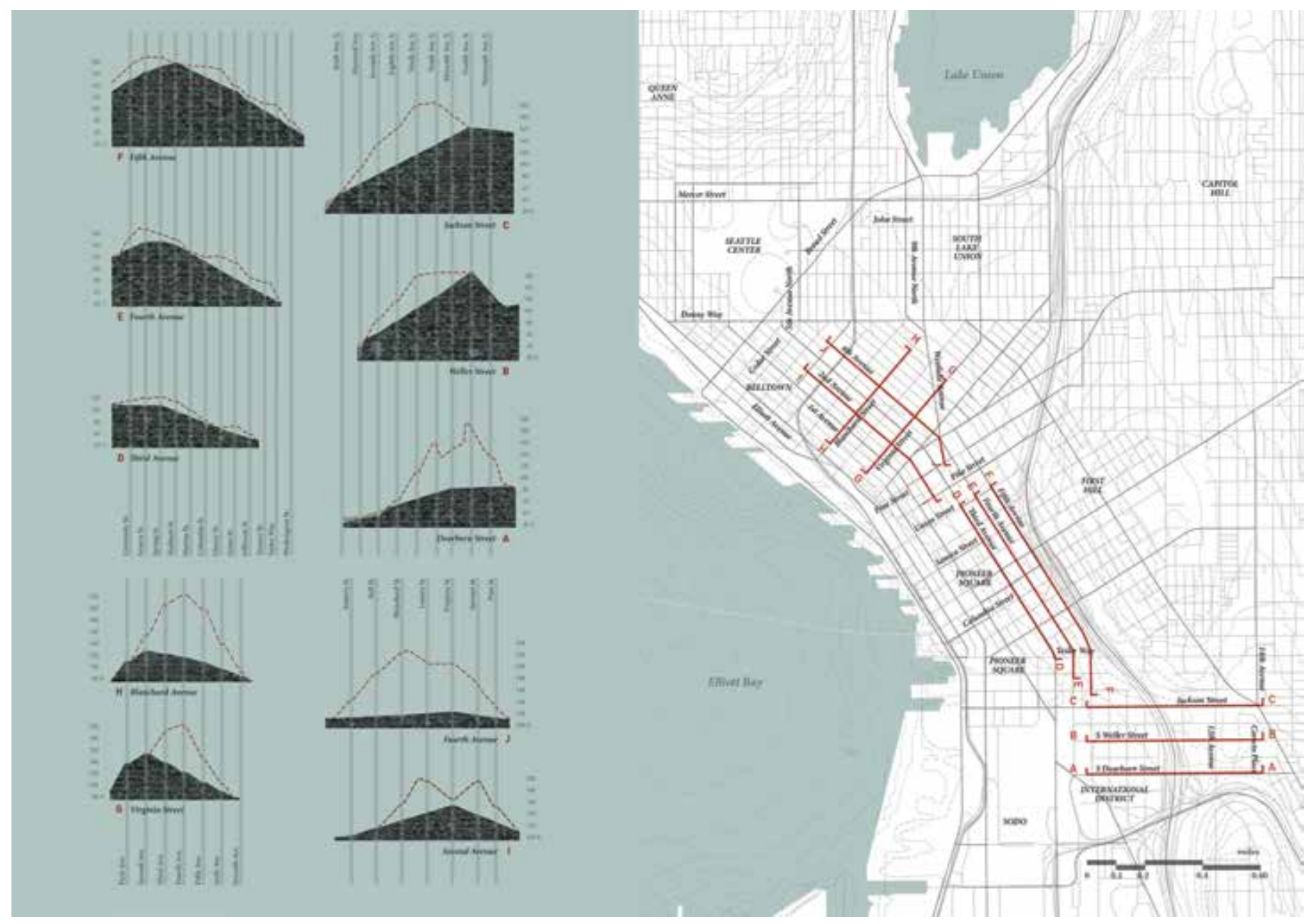

Figure 2. Profiles of the major regrades and their locations in Central Seattle. 
By the 1880s, Seattle had become the most important city in the Puget Lowlands, providing $22 \%$ of the coal produced on the Pacific Coast. ${ }^{20}$ San Francisco's rapid growth after the Gold Rush, fueled by coal, guaranteed lucrative returns for Seattle. Witnessing this success, attorney Thomas Burke saw the potential for another railroad. Constrained by tidal flats in the south, Burke's Seattle, Lake Shore and Eastern Railway was forced to take a northern route that detoured around a segment of the Northern Pacific Railway called the "Ram's Horn." A one-hundred-twenty-foot [36,6 m] wide right-of-way extending over the waters of Elliott Bay was granted in 1887, and would later be renamed from Railroad Avenue to Alaskan Way. Eventually, the waters between this railroad trestle and the actual shores would be filled in, effectively shifting the coastline west into the bay.

Another key industry in Seattle at that time was forestry. Many lumber mills populated the shoreline for ease of expansion over water, and the ability to dispose waste directly into the water. This submarine detritus consisted of: cinders from burnt coal; unwanted ceramics; glass and metals; pilings and planks used to support streets, piers and wharves; discarded bricks from old streets; ash from the Great Seattle Fire; and sawdust and wood from mills. ${ }^{21}$ To curtail the informal dumping, it was decided in 1916 that the "best" (as in, "cheapest" and "easiest") solution was to fill the space under the trestle and scaffolding with sediment, and define the western edge of Railroad Avenue with a seawall. All vestiges of the original shoreline were lost. Wharfed and armored, one could no longer descend to the water to experience the dynamism of this interface.

Denouncing the chaos along the Central Waterfront, planner Virgil Bogue advocated for the consolidation of ports under public ownership in 1895. The Port District Act was eventually passed in 1911 to officially create the "Port of Seattle." The conversion to a public port dismantled the railroad monopoly on the waterfront, which facilitated taxation, bonding, and condemnation for land acquisitions moving forward. ${ }^{22}$ As a condition of the Act, improvements had to be made on the waterfront, including dredging and straightening the Lower Duwamish River (LDR) ${ }^{23}$ for flood management, and the expansion of commercial and industrial uses upstream. What was once a shallow $9.3 \mathrm{mi}$. long [15 km] meandering river became a $5.3 \mathrm{mi}$. long $[8,5 \mathrm{~km}]$ straightened channel that is $50 \mathrm{ft}$. deep [15,2 m] for $4.5 \mathrm{mi}$. [7,2 km] of its new length. ${ }^{24} 20$ million cu. yd. $\left[15,3\right.$ million $\left.\mathrm{m}^{3}\right]$ of sediment were dredged to create this main channel and fill oxbows and river bends. ${ }^{25}$ Before entering Elliott Bay, the main channel splits into two waterways that define the 350-acre [141,64 ha] Harbor Island. ${ }^{26}$ To create this, 1.7 million cu. yd. [1,3 million $\left.\mathrm{m}^{3}\right]$ of fill were siphoned from the East Waterway, and 8 million cu. yd. [6,1 million $\left.\mathrm{m}^{3}\right]$ from the West Waterway, then dumped onto the naturally formed ćəqas (or "estuarial islands" in the Lushootseed language). ${ }^{27}$ By 1917, these islands were merged and $92 \%$ of the Duwamish tidal flats were filled in. 


\section{Restoring Ground}

Before being engineered for efficiency and control, the LDR was once a sediment-rich sinuous stream. It sat in a low gradient, subglacial trough incised by meltwater during the last Pleistocene glaciation. Aggraded above the glacial till is a layer of young Holocene alluvium, much of which could be attributed to lahars that avalanched down the valley during the Osceola Mudflow event 5700 years ago. ${ }^{28}$ This event had dictated how water drained within the Green-Duwamish river system. The historically meandering braided channels were nature's way of dissipating the energy of mudflows and fluvial flows by taking the longest path possible. The now-shortened path has limited opportunities for sediment deposition as river discharge is flushed directly into the bay. Seasonal fluctuations still occur with peak discharges after prolonged periods of winter rains and during early spring snowmelts, but flow rates have become highly regulated by the Howard Hanson Dam. Years of rapid prograding of the delta front

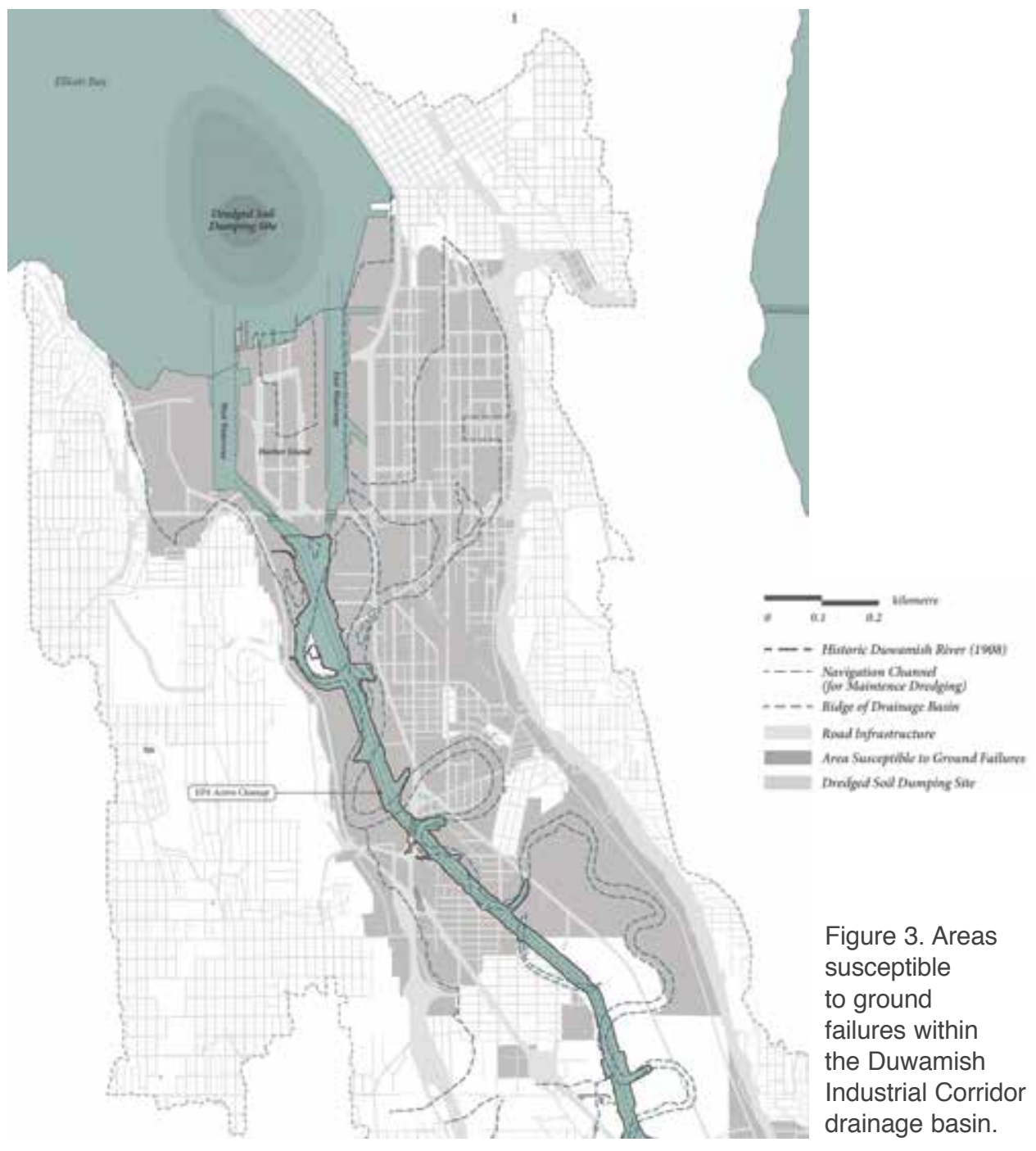


with sediment from Mount Rainier ran to a halt when the waterway was rendered static with armoured embankments and maintenance dredging.

The Green-Duwamish River was ranked as the fifth most endangered river in the United States according to a 2016 report by the non-profit environmental organization American Rivers. ${ }^{29}$ Some 412 acres [166,73 ha] of the LDR has been designated as a Superfund site as of 2001, due to a history of industrial pollution, stormwater runoff, and Combined Sewer Overflow events that contributed toxic wastes to this river system..$^{30}$ The World Wars had accelerated industrialization without the strict policing of pollutant discharge, thus causing the health of the Duwamish River to deteriorate. In 1988, the United States Environmental Protection Agency (EPA) conducted an investigation into the harmful chemical compounds and toxic metals found in the LDR (Fig. 3). The following contaminants were deemed to pose the greatest human health risk: polychlorinated biphenyl, arsenic, polycyclic aromatic hydrocarbons, and chlorinated dioxins and furans. ${ }^{31}$ Long-term exposure to this toxic environment, especially through seafood consumption, can be detrimental to human and wildlife health.

The EPA has begun implementing a remediation plan to clean up years of unregulated pollution. However, "remediation" may not be the operative word as the EPA plan does not actually cure or rectify the problem; it seeks only to relocate, bury, or simply observe it. An external advisory board suggested the elimination of Monitored Natural Recovery (MNR; essentially a "no treatment" method) from the initial plan, yet revisions were slight. The Final Proposed Plan for Cleanup will consist of 57\% MNR; 25\% dredging of contaminated materials; $12 \%$ Enhanced Natural Recovery (ENR; the use of a thin layer of sand to speed up natural deposition); and $6 \%$ capping with clean materials. The reliability of the ENR and MNR methods is largely dependent on the amount of sediment carried by the river and how it settles. Moreover, capping is not a foolproof method as construction and dredging may resuspend contaminants from semi-stable conditions. Fishing practices where nets are dragged along river beds also risk unearthing contaminants. The tainted equipment would then contaminate our food supply. Likewise, burrowing organisms may dig past clean sediment to exhume and consume toxins, which would then find their way up the food chain.

Large-scale public works like the EPA remediation plan provides an opportunity to consider issues of long-term ground hazards. The LDR flows precariously across the Seattle Fault, where the $12.4 \mathrm{mi}$. [20 km] thick Crescent Formation would push up over a higher stratum of rock in the event of an earthquake. The land bulging may re-expose capped contaminants and flood communities with polluted waters. At the micro level, the intense tremors would increase the already high pore pressures of water-saturated soils beyond their interparticle contact stresses, causing soils to liquefy. This may unleash submarine landslides at the north end 
of Harbor Island, the delta front of the Duwamish River. Again, this could resuspend contaminants. Pollutants may also leach through soils and contaminate groundwater with the concurrent rise of the water table and sea level.

Since sequestering contaminants is never fully effective for all projects, the ideal method of cleanup is bioremediation, which relies on in-situ decomposition using microbes to break down contaminants over time. The key to success for this process is dispersal and dilution: flushing out and deconcentrating contaminants increases the surface area for microbes to operate. In the interest of ecosystem health and environmental justice, ${ }^{32}$ restoration methods should ensure the complete detoxification of the waterway.

\section{BALANCING SEDIMENT WITH ADAPTIVE STRATEGIES}

Over the past century, the LDR has been so heavily altered and stabilized that it would be impossible to return it to its "natural" condition. But rather than positing what is "natural," perhaps we should accept that a complete reversion would be neither realistic nor ideal. It disregards the progress made to transform the LDR into a productive landscape that serves as the state's main revenue generator. However, for the industrial corridor to be robust enough to cope with impending catastrophic disasters while respecting the ecological health of the river basin, a paradigm shift is needed. This project argues for a balance of sediment uses to achieve Ecosystem Resilience, rather than exploiting this resource for Engineering Resilience.

\section{Visualizing Cycles}

Lance H. Gunderson and C.S. Holling's theory on adaptive cycles applies the meta-stable equilibrium to both natural and disturbed ecosystems, where changes may be episodic, as opposed to than gradual or relentlessly stochastic. Ecosystems do not tend toward a single equilibrium, but rather homeostasis can be found at multiple equilibria. Gunderson and Holling argue for a shift from Engineering Resilience to Ecosystem Resilience. This means shifting from a command-and-control approach that lingers at the micro-level, to a more comprehensive approach that considers adaptive enterprises at the macro-level. ${ }^{33}$ This means shifting from solutions based on efficiency and a predictable, steady-state equilibrium to solutions that maintain functionality by moving from one stability domain to the next in search of stasis.

The adaptive cycle provides a way of understanding ecosystem dynamics through flows between four distinct phases. Capital accumulates slowly during Exploitation ( $r$ ) and gradually becomes tightly bound and resistant to change entering Conservation $(\mathrm{K})$. This eventuates in "creative 
destruction" ${ }^{34}$ or Release $(\Omega)$, from which the ecosystem Reorganizes (a) and opens up to novel recombinations. Applied to earthquakes, stress (as capital) is slowly built up as interlocked plates move against each other. Once the threshold is reached, there is a sudden release of stress as a temblor. After the ground reorganizes and settles, the cycle restarts. Cycles can be found within cycles as well. Unperceivable slow slip events have been occurring every fourteen to fifteen months off of Vancouver Island. ${ }^{35}$ These episodic tremors are miniature releases of pent-up stresses that usually portend an earthquake associated with a higher level cycle - like the "Next Big One" (Figs. 4, 5). The increased frequency of these events acts as an indicator of impending regime change.

This complex organization of ecosystems across space and time can be represented by "panarchy," the nesting of adaptive cycles at semiautonomous levels connected by their asymmetrical interactions (Fig. 4). A fall from a large and slow cycle to a smaller and faster cycle is called Remembering. The patterns from the higher, mature cycles inform changes at the lower cycles. A jump in the opposite direction is called Revolting, where a crisis triggers or amplifies "creative destruction" at a higher cycle. For example, an earthquake may cause restructuring in the soil matrix that is "remembered," thus increasing the potential for landslides at a lower cycle. Slopes become more prone to landslides with increased water saturation, which can result in a "revolt" to a higher cycle and exacerbate destruction during an earthquake.

Resilience is introduced when the adaptive cycle is visualized in 3-dimensions and rotated on the Potential axis (Fig. 4). Resilience increases as the cycle moves away from the connectedness of $\mathrm{K}$ and $\Omega$
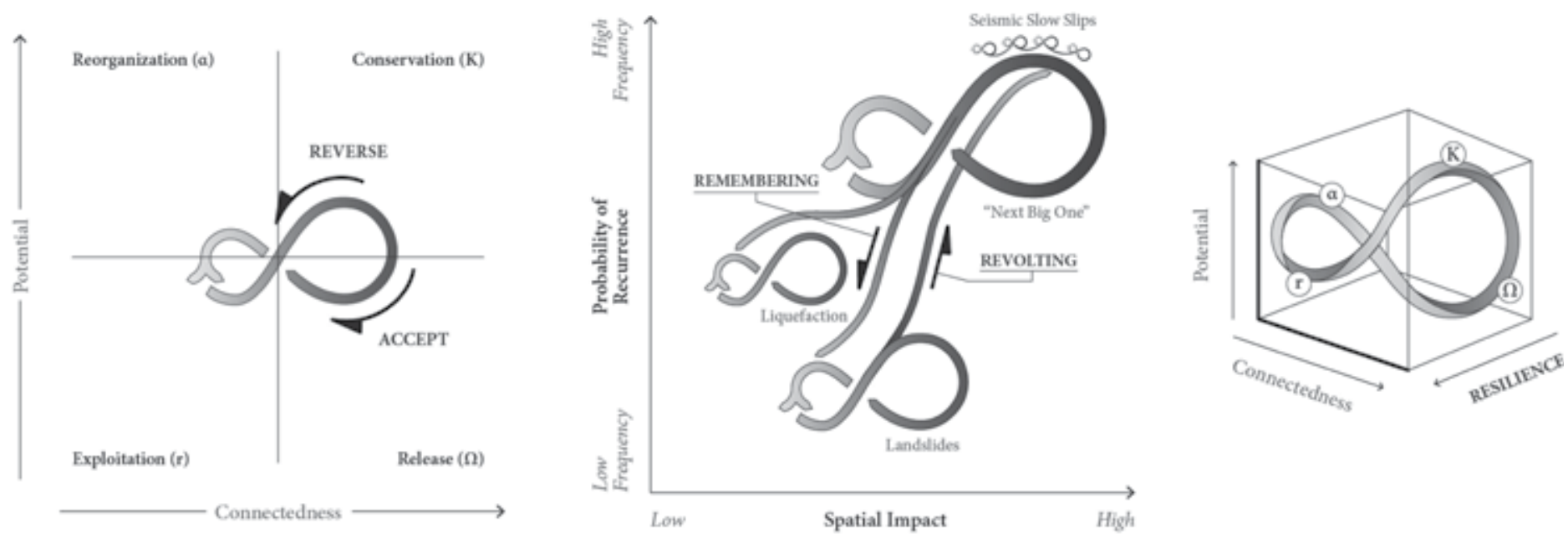

Figure 4. Concepts of the "adaptive cycle", "panarchy" and "resilience" applied to ground failures. 
and into the reorganizing functions of $a$ and $r$. In $a$ and $r$, the cycle is more amenable to disturbances and surprises, facilitating creative change or adaptation. When confronted with discontinuities, a resilient system will recalibrate to a new equilibrium and maintain its functionality.

\section{Calculating a Sediment Budget}

To be able to shift between equilibria when dealing with ground failures, designers should develop a fluency in balancing sediments in our coastal systems by using a sediment budget. Understanding how sediment is circulated in the Puget Lowlands can inform how the resource is controlled, conserved, and reallocated for adaptive strategies that anticipate ground failures. The sediment timeline (Fig. 5) reveals how this resource was recycled in past earthwork projects, as opposed to being completely
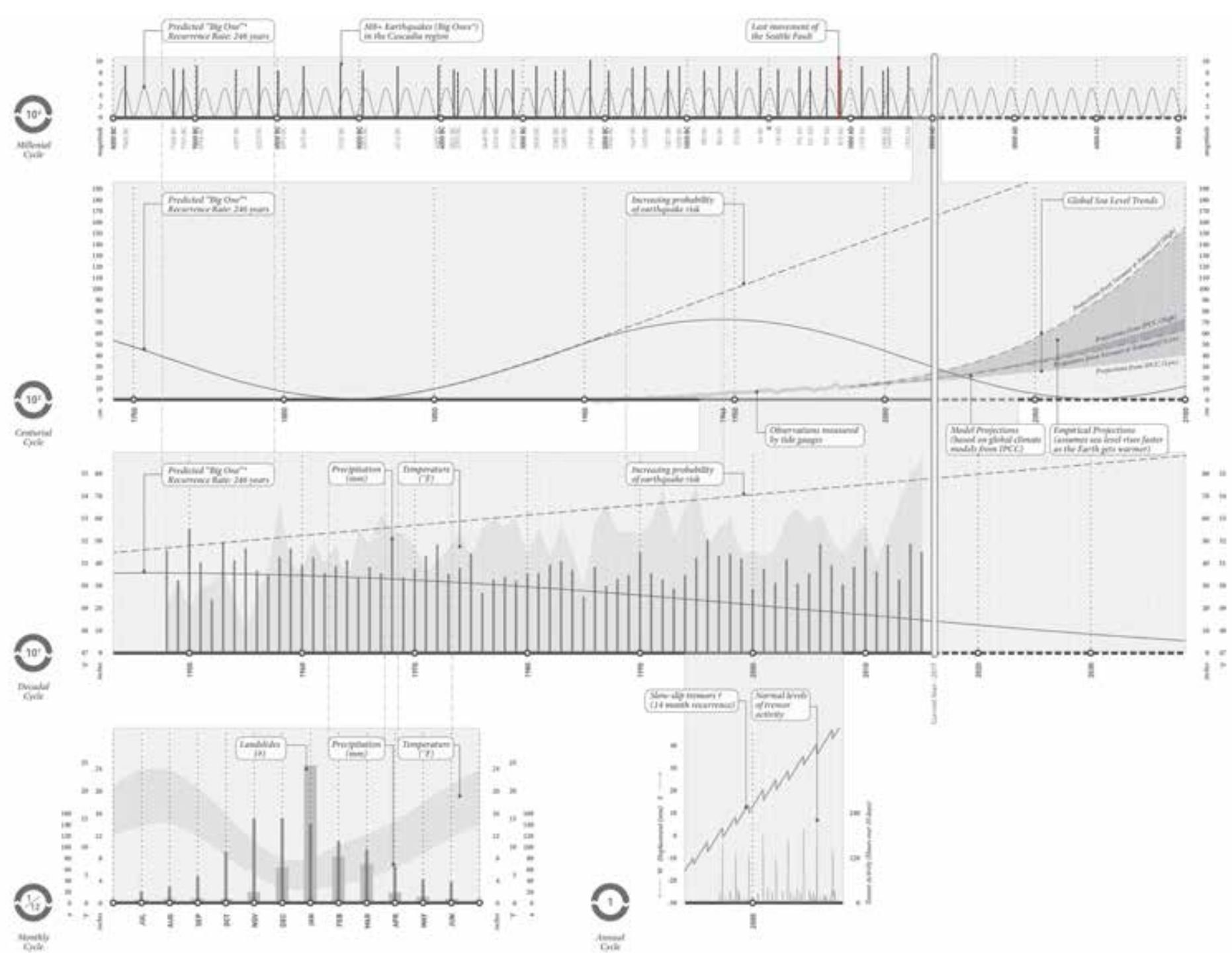

Figure 5. Timelines of ground hazards (earthquakes, slow slips events, climate change, sea level rise, landslides) measured at different time scales. 
removed from the system in recent projects. $790,000 \mathrm{cu}$. yd. [603.998 $\mathrm{m}^{3}$ ] of contaminated soils from the EPA cleanup of the LDR will be discarded to the Roosevelt Regional Landfill approximately $300 \mathrm{mi}$. [483 km] away. ${ }^{36}$ 850,000 cu. yd. [649.871 $\mathrm{m}^{3}$ ] of spoils will be excavated for the State Route 99 Tunnel, of which the clean portion will be barged to Port Ludlow to fill an abandoned quarry site. ${ }^{37}$ This "out of sight, out of mind" mentality only takes the problem and relocates it. Moreover, the permanent deficit of sediment throws the ecosystem off-balance.

Generally, sediments from upland "sources" are carried by currents to lowland areas, where they are deposited in "sinks" (Figs. 6, 7). Coasts advance and retreat with natural sediment delivery and erosion, but this can also be affected by human interventions within the littoral cell. Dredging and damming interfere with the transport of optimally sized sediment needed for

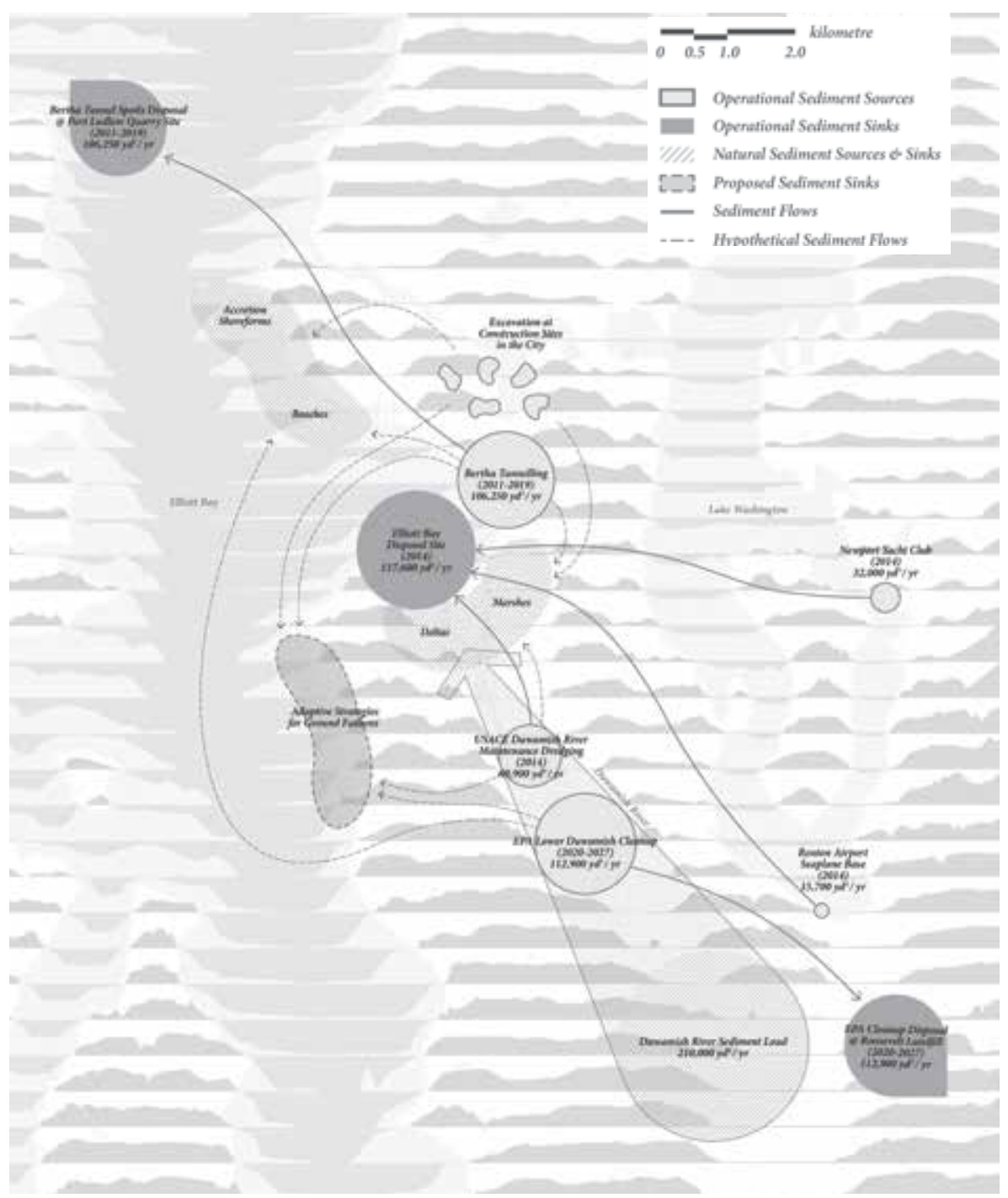

Figure 6. Annual sediment flows, sources and sinks for natural processes and earthwork operations in the Puget Lowlands. 
salmon spawning grounds. These operations also result in a net land loss, whereby sediment accretion is reduced and cannot keep up with sea level rise. To protect from inundation, we resort to the use of manmade coastal barriers, but this again inhibits sediment supply and changes the natural formation of shorelines and their ecosystems. For example, artificially stabilized shorelines prevent sediment from forming deposition bars, behind which tidal wetlands are created.

Treating sediment as a resource or capital, how might a designer intervene with adaptive cycles in mind? Here, my thoughts deviate from Gunderson and Holling: I believe innovation is not limited to the break in cycle between $a$ and $r$. If resilience increases towards $a$ and $r$, there may be two ways of pursuing resilience throughout the cycle (Fig. 4). Resisting release $(\Omega)$ by attempting to "reverse" the cycle is the epitome of engineering mentality. Suppressing potential may delay the disaster, but can lead to greater consequences. Learning to "accept" the release as part of the balancing act can accelerate renewal or recovery, and thereby improve the metabolism of an ecosystem. Strategies addressing ground failures are evaluated on an adaptability scale from "reverse" to "accept," or from Engineering Resilience to Ecosystem Resilience. Ecosystem Resilience is preferred as it can adapt to new equilibria, while Engineering Resilience fights to remain in the same stability domain. A range is provided as complete "acceptance" is not always feasible due to: the necessary protection of assets, the permanence of existing infrastructure, a predisposition that favors short-term cost savings over long-term gains, the risk and uncertainty associated with novel approaches, and resistance to multidisciplinary collaborations.

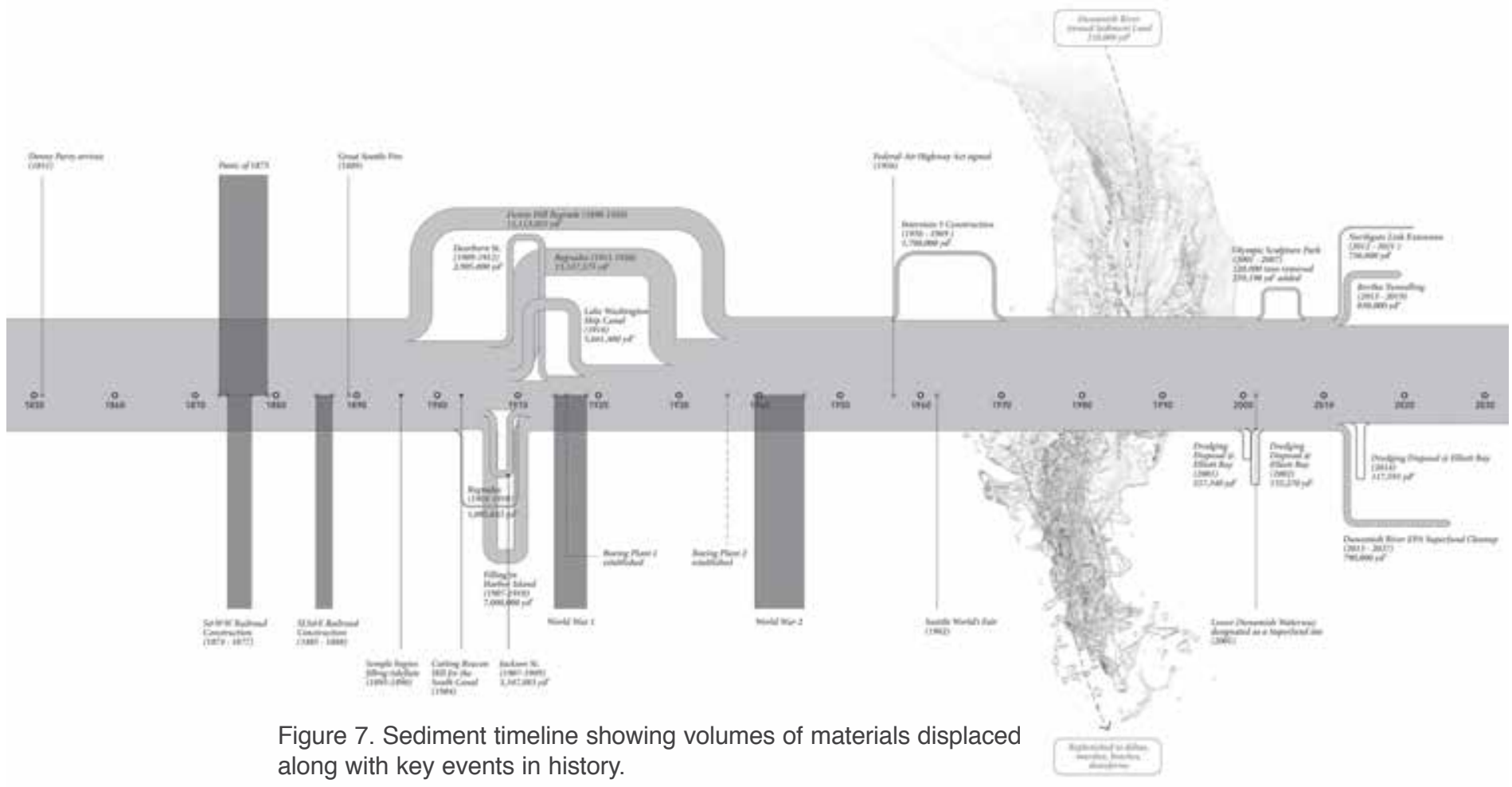




\section{Cataloguing Adaptive Strategies}

For designers to reach an informed decision, "The Catalogue" deconstructs ground failures by first examining the fundamentals of (hydro) geomorphology and the mechanics of earthwork operations. Ground failures are divided into two categories: Gravitational Instabilities (ground failures that involve mass displacement caused by the vertical force of attraction to the center of the Earth) and Lateral Vulnerabilities (ground failures marked by changes in datum). Typologies of adaptive strategies for each category are proposed and sorted according to either the location of intervention on a hillslope (for Gravitational Instabilities) or the landform profile relative to predicted sea levels (for Lateral Vulnerabilities). Each typology is rated on the adaptability scale from "reverse" to "accept," and an estimated percentage of cut and fill is provided to maintain a balanced sediment budget across all earthwork operations (Figs. 8, 9).

\section{Masterplanning Scenarios}

Typologies are selected from "The Catalogue" and applied to a masterplan of the Duwamish Corridor, which articulates the region's transformation over the next 100 years. The order which strategies will be executed is determined by when ground hazards are expected to occur, their probability of occurrence, their degree of impact, and the value of losses they incur. The proposed scenario begins with building tunnels to protect railroads from seasonal landslides, and addressing exigent concerns of soil toxicity by carving channels to dilute contaminants for bioremediation. Next, port facilities will be floated offshore ${ }^{38}$ to vacate sites for land readjustments and infrastructure renewal. Slopes will be fortified while simultaneously providing affordable housing over "lidded" ${ }^{39}$ highways. Major arterials and developments will gradually be elevated above rising sea levels and lahar flows from the next Mount Rainier eruption (Figs. 10, 11). Decoupling development from the ground allows the Duwamish River to flow unconstrained, thus cleansing sediment of contaminants, replenishing the basin with new sediment, and providing space for lost ecosystems to revitalize. Respecting sediment processes and restoring sediment health are critical in building resilience to ground hazards in Seattle.

\section{Moving Forward}

To further develop, refine, and validate this methodology, the following items need to be addressed:

- Spatializing the cascading effects that multiple hazards have on critical assets.

A 3D modelling software may be more effective in visualizing impacts on value at risk and their temporal complexities, than simply superimposing weighted overlays on a risk zone map (Fig. 1). 
This medium is also better suited for comparing adaptation scenarios.

- Identifying cost implications for each typology.

The feasibility of each typology is a function of the risks reduced and the costs incurred when reviewing the sediment budget as a whole. Although appraisals should be conducted on a case-by-case basis, costs estimates (e.g. based on the volume of soils displaced, the distance transported, and the degree and means of manipulation) are useful in typology selection for masterplanning.

- Devising a feedback loop.

A self-regulating mechanism should be in place to periodically assess the performance of adaptive strategies and reconfigure as necessary. Plan reviews and updates should be expected every five years (or less).

- Collaborating with experts to resolve problems related to complex systems.
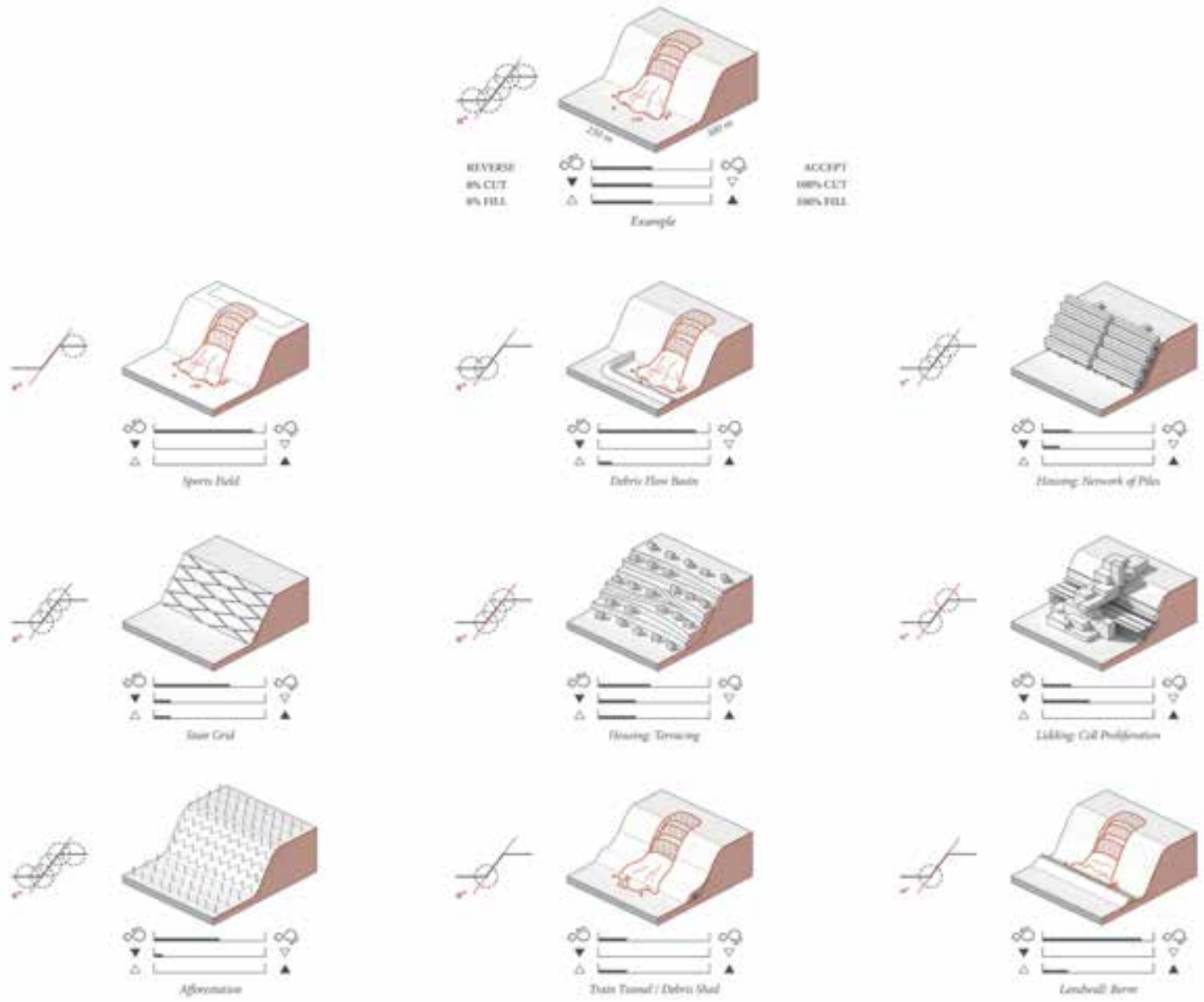

Figure 8. Excerpt from the "Sediment Catalogue" of adaptive strategies for "Gravitational Failures." 
Complex systems require interdisciplinary working groups to promote diversity in dialogue, challenge assumptions, prompt change, and help disseminate ideas.

Aligning projects with shared goals can increase chances of influencing policies; improve efficiency by avoiding redundancies; and provide a platform for sharing technical expertise, information, and resources. My project can offer a design perspective to teams operating across disciplines to reduce the impacts of multiple hazards, such as: The University of Washington's M9 Project, or the Mitigation Work Group assembled for the "City of Seattle All-Hazards Mitigation Plan."

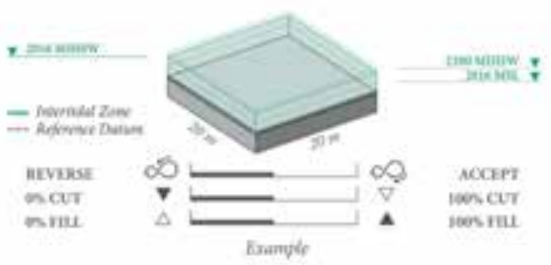

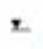
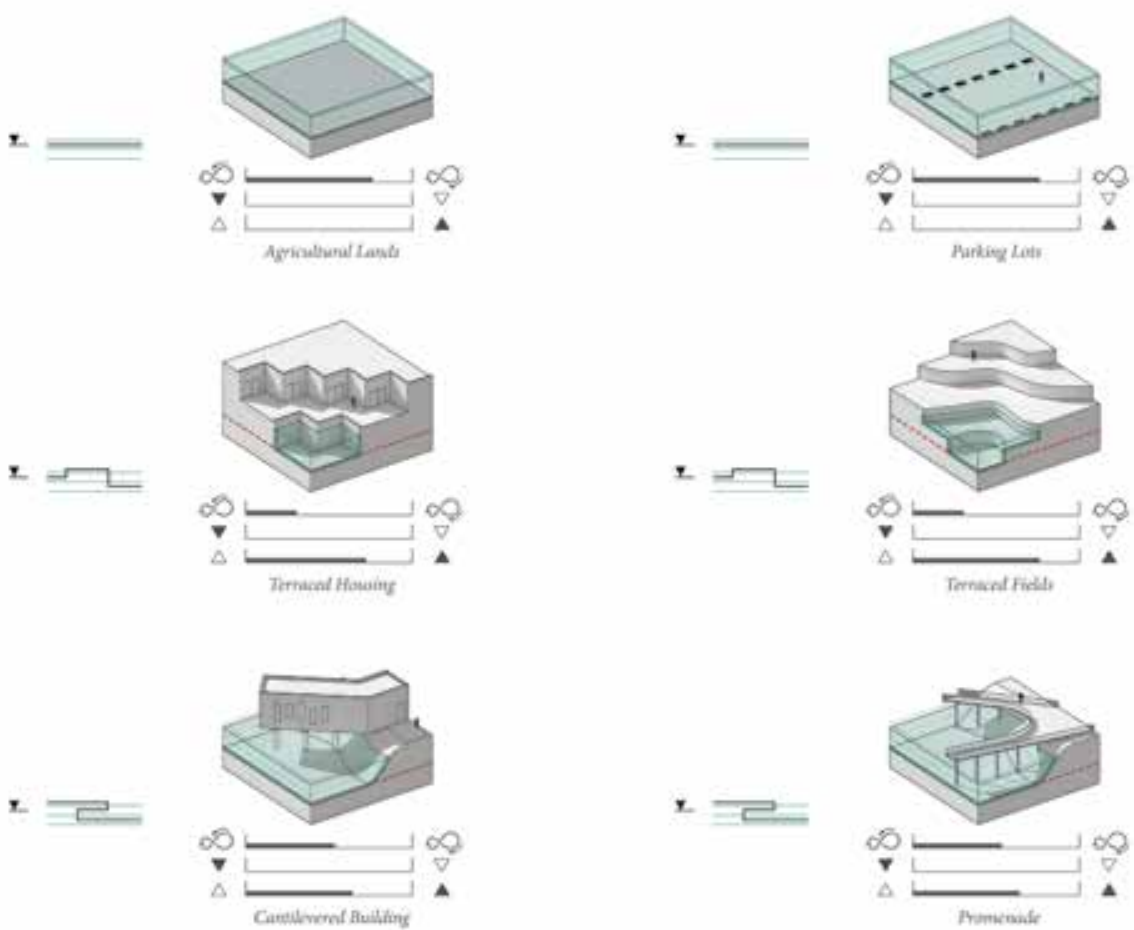

$\square$

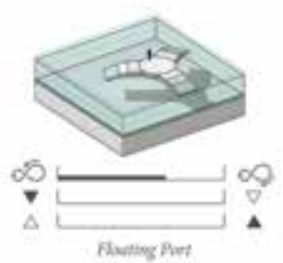

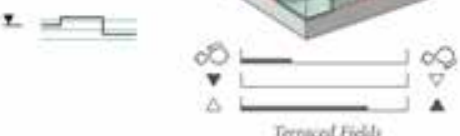
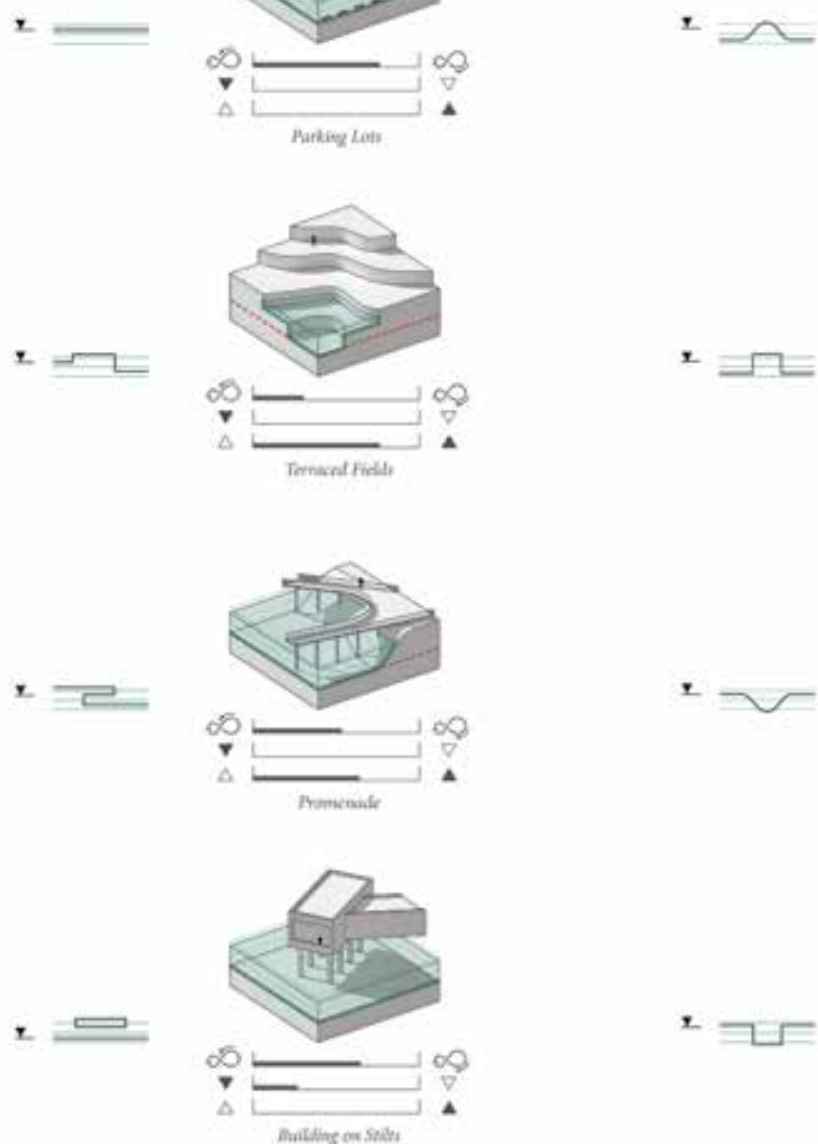

.

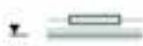

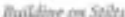

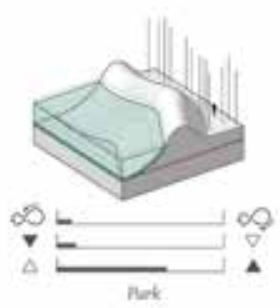

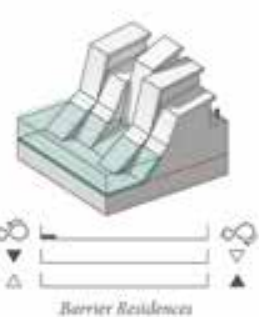
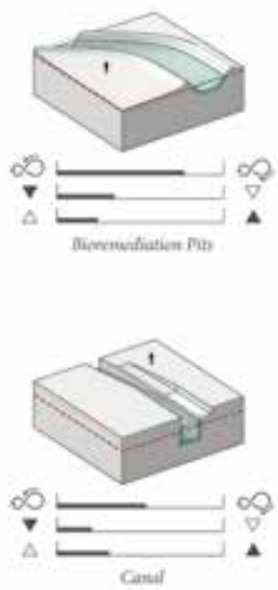

Figure 9. Excerpt from the "Sediment Catalogue" of adaptive strategies for "Lateral Vulnerabilities." 


\section{ACTION AS DISPOSITION}

Following the region's largest disaster drill, "Cascadia Rising," state officials criticized their inadequacy in disaster response, with the blunt admission that "Washington is not currently a resilient state." 40 They do, however, recognize the long-term mitigation efforts made in the "Resilient Washington State Initiative," ${ }^{41}$ which outlines seismic risk reduction policies and actions for the next 50 years. The 2012 report led to the convening of the Resilient Washington Subcabinet four years later. At the city level, seismic retrofit programs and capital projects have progressed, albeit at varying paces. The City of Seattle's Office of Emergency Management (OEM) helps facilitate their implementation across departments. The OEM is a nationally accredited agency that manages and coordinates resources and responsibilities for all types of hazards. Their emergency operations and training exercises are conducted from a command-and-control center annexed to Seattle's Fire Station 10. This is also the headquarters for the administration of outreach programs, planning initiatives, and grant applications.

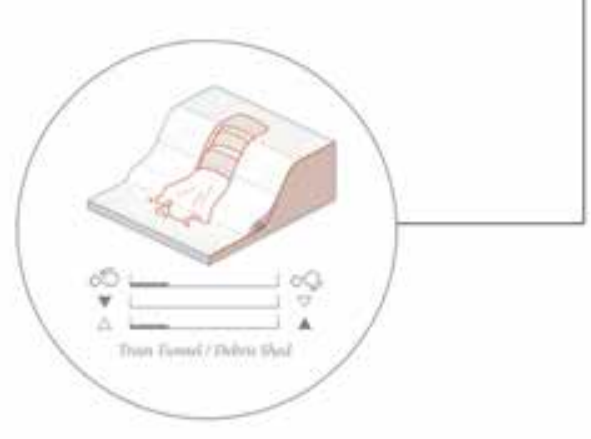

$\perp^{m m}$

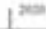
1 in

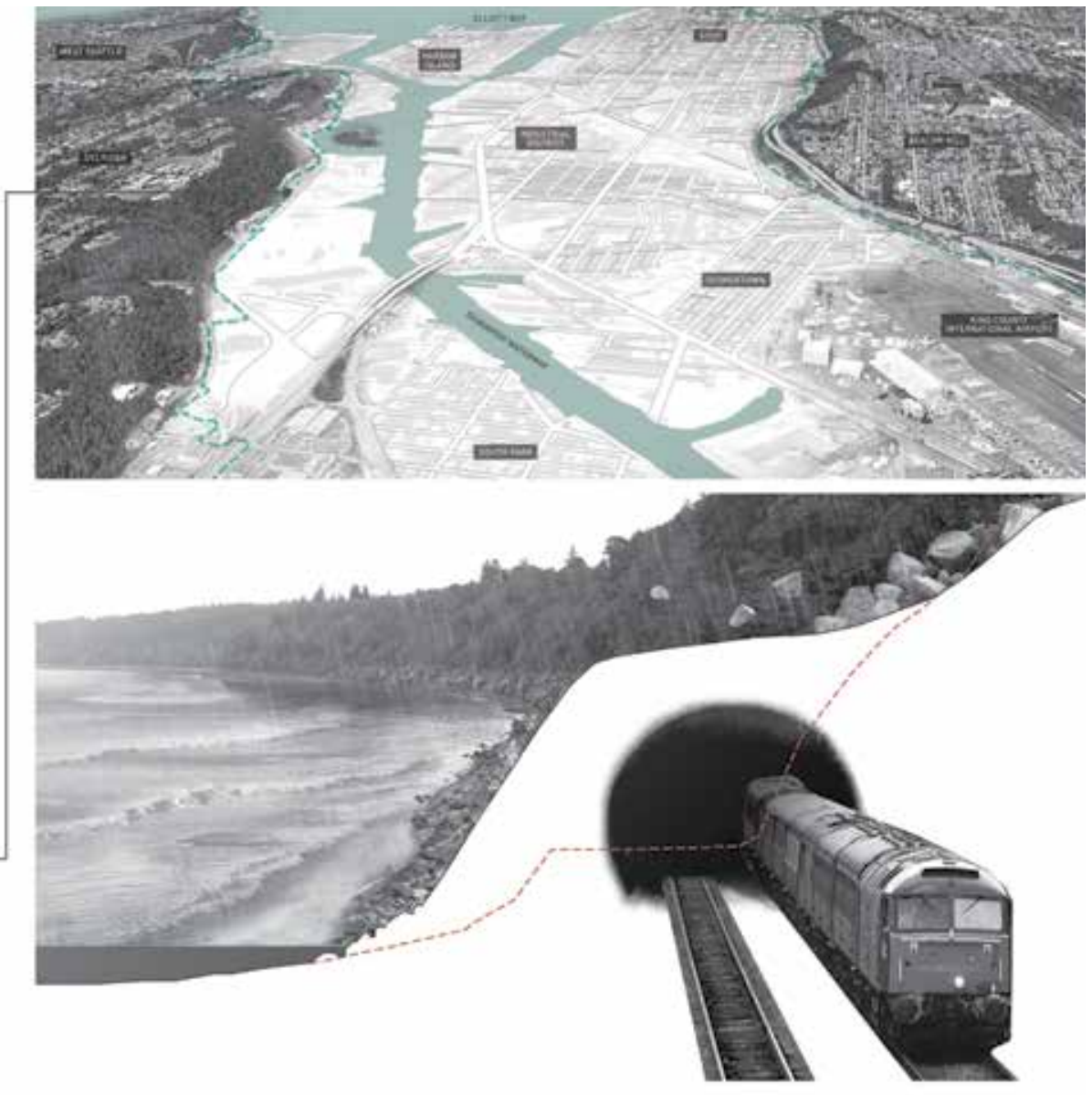
1 im $1 \mathrm{~min}$ $1=$ $1=$ Iin Figure 10. Excerpt from the masterplan applying adaptive strategies over the next 100 years (1 of 2). 
As of 2016, the OEM's "2015-2021 All-Hazards Mitigation Plan" was approved by the Federal Emergency Management Agency (FEMA), making it eligible for grants funded by the Stafford Act, contingent on five year reviews. One of the objectives was to produce an implementation plan that recommends mitigation actions by City department for the next five years. It lists project durations, anticipated costs, and funding sources, and scores each on their suitability and effectiveness. While this satisfies short-term trajectories and desires for quick-fixes, ${ }^{42}$ my project offers a framework for designing long-term resilience to ground hazards in urban contexts using a case study approach.

Comfort in a conventional, linear approach makes it easy to validate counterproductive metrics that fail to identify the crux of the problem, leading to misplaced resources, exacerbated risks, and missed opportunities. Grounded by the theoretical underpinnings of "panarchy," my provocations apply systems-thinking to first redefine the problem. Published over a decade ago, "panarchy" has been used to understand complex systems in ecology, governance, law, and urban planning, yet
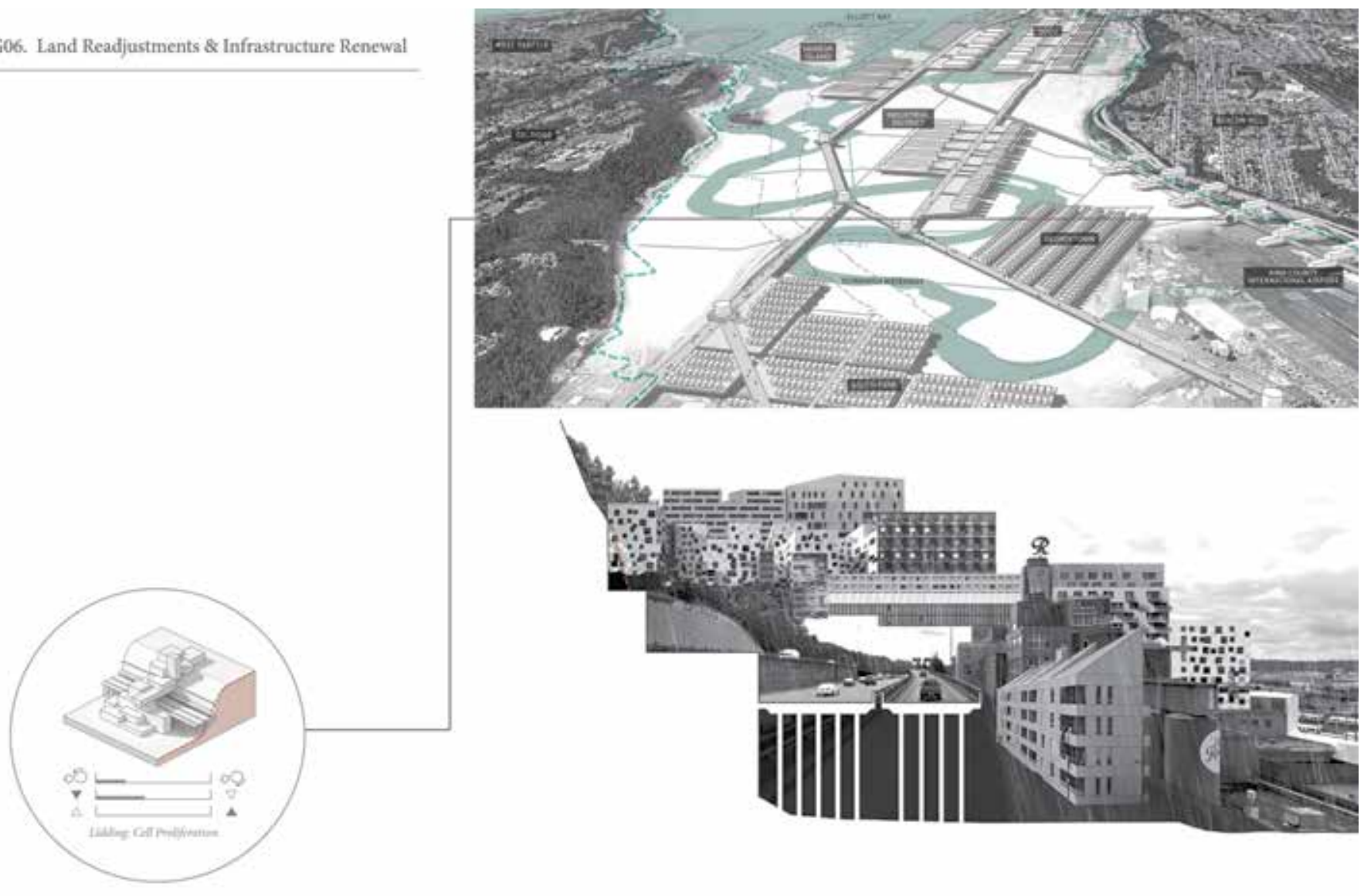

tak $1=n$

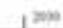<smiles></smiles>

$1^{\text {ne }}$

$1^{\mathrm{m} n}$

$L^{\text {nowe }}$

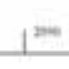

$I^{\text {Hin }}$ nus

Figure 11. Excerpt from the masterplan applying adaptive strategies over the next 100 years (2 of 2). 
its application awaits evidence-based testing due to the lack of long-term datasets. With that said, disaster contingency planning does not have the luxury to allow analyses to incubate in the face of crises. Building on a prevailing resilience discourse that has resonated across disciplines, ${ }^{43}$ my framework of adaptive strategies foregrounds "action" as a means of developing and defining a disposition. Filtered through the discursive methods of design research, the project is structured to evolve theory into practice using a performance-based methodology. The urgency of the impending risks demands it, and the versatility of the framework allows it.

The strategies are perhaps synonymous to what Keller Easterling refers to as "active forms." As she describes in "Action is the Form:" "The designer of active forms is perhaps designing not just an enclosure or an urban boundary but a disposition for the growth or even contraction of space. The author of software is not the author of all of the forms that flow through that software, but rather the author of a platform that shapes and manages information." ${ }^{44}$ I have proposed not one single, pervasive strategy, but rather a series of strategies - or active forms - that affect how the field is inflected over time. Solutions are not prescribed, but rather presented as possibilities. With all possibilities laid out, strategies can easily be reconfigured as risks change in an indeterminate system. The expandable catalogue of strategies gives space for invention. When confronted with the (impending) failure of a system, "the situation demands innovation," 45 suggests Mark Wigley in "Space in Crisis." When the limits of a problem are not clear, he calls on "radical intervention" to reestablish those limits: "The crisis is such a radical threat to the environment that it acts as a kind of demand for whole new kinds of policies, procedures, and people." 46 If crises are catalysts for change, my adaptive strategies set new limits to mitigate the impacts of inevitable destruction using a new form of preemptive "production" - this is the tenet of the adaptive cycle.

\section{Notes}

1. The definition of sediment as "earthly or detrital matter deposited by aqueous agency" (according to the Oxford English Dictionary) is expanded to be consciously unassociated with any geological time scales. For example, this may include glacial alluvium that has since been altered by human activity. The use of sediment, in this case, is relevant due to the fluvial and coastal setting of the Duwamish Industrial Corridor. Oxford English Dictionary, s.v. "sediment, n."

2. Ralph A. Haugerud, D.B. Ballantyne, C.S. Weaver, K.L. Meagher, and Elizabeth A. Barnett, "Lifelines and Earthquake Hazards in the Greater Seattle Area," U.S. Geological Survey, last modified June 12, 2015, https://geomaps.wr.usgs.gov/pacnw/lifeline/eqhazards.html. 3. Kate Allstadt, John Vidale, and Arthur D. Frankel, "A Scenario Study of Seismically Induced Landsliding in Seattle Using Broadband Synthetic Seismograms,"

Bulletin of the Seismological Society of America 103, no. 6 (December 2013): 2987, http://dx.doi.org/10.1785/0120130051.

4. "View properties" are typically residences built on hillslopes to capture expanses of views, mostly natural. In Seattle, most view properties overlook Puget Sound and Lake Washington. 
5. Kathy Goetz Troost and Derek B. Booth, "Geology of Seattle and the Seattle Area, Washington," in Landslides and Engineering Geology of the Seattle, Washington, Area, eds. Rex L. Baum, Jonathan W. Godt and Lynn M. Highland (Boulder CO, USA: The Geological Society of America, Inc., 2008): 1-36, 15.

6. Allstadt et al., "A Scenario Study," 2983.

7. National Research Council (USA), ed., Sea-Level Rise for the Coasts of California, Oregon, and Washington: Past, Present, and Future (Washington DC: National Academies Press, 2012): 9, https://doi.org/10.17226/13389.

8. Philip Mote, Alexander Petersen, Spencer Reeder, Hugh Shipman, and Lara Whitely Binder, Sea Level Rise in the Coastal Waters of Washington State (Seattle: Climate Impacts Group; Olympia: Dept. of Ecology, State of Washington, 2008): 10.

9. Kit Oldham and Peter Blecha, The Story of the Port of Seattle: Rising Tides and Tailwinds: 1911-2011 (Seattle WA, USA: University of Washington Press, 2011): 75.

10. Arthur H. Dimock, "Preparing the Groundwork for a City: the Regrading of Seattle, Washington," Reprinted from Transactions American Society of Civil Engineers 92, Paper no. 1669 (1928): 720.

11. Greg Lange, "Denny Regrade Second Phase Is Completed on October 31, 1911,"

HistoryLink.org, last modified January 16, 1999, http://www.historylink.org/index.

cfm?DisplayPage=output.cfm\&file_id=710.

12. David B. Williams, Too High \& Too Steep: Reshaping Seattle's Topography

(Seattle WA, USA: University of Washington Press, 2015): 149.

13. Greg Lange, "Denny Regrade (Seattle) Contract for Second Phase Is Issued August

29, 1903," HistoryLink.org, last modified January 15, 1999, http://www.historylink.org/index. cfm?DisplayPage=output.cfm\&file_id=709.

14. Williams, Too High \& Too Steep, 157.

15. Dimock, "Preparing the Groundwork for a City," 721.

16. R.M. Overstreet, "Hydraulic Excavation Methods in Seattle," Engineering Record 65, no. 18 (May 4, 1912): 481.

17. Dimock, "Preparing the Groundwork for a City," 721; Lange, "Denny Regrade Second Phase."

18. "Retooling" suggests that during the industrialization of the Duwamish Corridor, the reworked ground was treated like "a machine for a new operation." Oxford English Dictionary, s.v. "retool, v."

19. John Collins, Mayor, "Ordinance No. 44," Puget Sound Dispatch 2,

no. 36 (August 21, 1873).

20. Williams, Too High \& Too Steep, 74.

21. Williams, Too High \& Too Steep, 48.

22. Oldham and Blecha, The Story of the Port of Seattle, 28.

23. The Green-Duwamish river system includes all tributaries that drain from the same watershed. The Lower Duwamish River (LDR) is the last segment of this system before entering Elliott Bay.

24. United States Environmental Protection Agency, "Environmental Justice Analysis for the Lower Duwamish Waterway Cleanup," (February 2013): 8, https://www3.epa.gov/region10/pdf/ sites/ldw/pp/ej_analysis_Idw_feb_2013.pdf.

25. David Wilma, "Straightening of Duwamish River begins on October 14, 1913," HistoryLink. org, last modified February 16, 2001, http://www.historylink.org/File/2986.

26. David Wilma, "Harbor Island, at the Time the World's Largest Artificial Island, Is Completed in 1909," HistoryLink.org, last modified November 6, 2001, http://www.historylink.org/File/3631. 27. Williams, Too High \& Too Steep, 96-97.

28. Troost and Booth, "Geology of Seattle," 14.

29. America's Most Endangered Rivers ${ }^{\circledR}, 2016$, https://americanrivers.org/threats-solutions/ endangered-rivers/.

30. "Superfund Info," Duwamish River Cleanup Coalition, http://duwamishcleanup.org/ superfund-info/.

31. "Urban Waters Initiative - The Lower Duwamish: History and Promise," Department of Ecology State of Washington, http://www.ecy.wa.gov/urbanwaters/duwamish.html.

32. Environmental justice is an important consideration in choosing restoration methods as affected communities consist of underprivileged, minority groups that lack environmental education and English language proficiency, and have limited channels of communication with policymakers. 
33. Lance H. Gunderson and C. S. Holling, Panarchy: Understanding Transformations in Human and Natural Systems (Washington DC: Island Press, 2002), 28.

34. "Creative destruction" is a term borrowed from economist Joseph Schumpeter and used in theories on socio-ecological systems by C.S. Holling and Lance H. Gunderson.

35. Johanna Wagstaffe, "Why the Risk of the 'Big One' in B.C. Is Heightened Every 14 Months," CBC British Columbia (October 11, 2016), http://www.cbc.ca/beta/news/canada/ british-columbia/earthquakes-bc-slow-slip-1.3794192.

36. United States Environmental Protection Agency (EPA) Region 10, "Proposed Plan: Lower Duwamish Waterway Superfund Site" (February 28, 2013): 2,300 mi. is the approximate travel distance by rail, https://www3.epa.gov/region10/pdf/sites/ldw/pp/ldw_ pp_022513.pdf.

37. "FAQs," Washington State Department of Transportation, 2016, http://www.wsdot. wa.gov/Projects/Viaduct/Faqs.

38. This is a reference to explorations by the Lawrence Livermore National Laboratory (LLNL) to relocate port security operations to pneumatically stabilized platforms offshore. If the timing is right, speculative projects can benefit from mutual validation to improve the likelihood of implementation. Integrating concepts of floating ports into the adaptive strategies for ground hazards is an example of this.

39. "Lidding" comes from the idea of covering highways to reclaim land and reestablish connections across the open-ditch construction. Architect Paul Thiry and the First Hill Improvement Club had been opposed to the construction of Interstate 5 through Seattle, and were the first to propose lidding the highway with development. Since then, the case for lidding Interstate 5 has been revisited many times to no avail. The only attempts at lidding were by the Freeway Park (1976) and the Washington State Convention and Trade Center (1988). 40. Washington State Military Department, Washington State 2016 Cascadia Rising Exercise After Action Report: Catastrophic Earthquake and Tsunami Scenario (January 5, 2017), https://mil.wa.gov/uploads/pdf/training/cr16-state-aar-final.pdf.

41. Washington State Seismic Safety Committee, Resilient Washington State: A Framework for Minimizing Loss and Improving Statewide Recovery after an Earthquake (Olympia WA, USA: Washington State Department of Natural Resources, Division of Geology and Earth Resources, November 2012), http://wa-dnr.s3.amazonaws.com/publications/ger_ic114_ resilient_washington_state.pdf.

42. Sandi Dougton and Daniel Gilbert, "Inslee's Quake Group Favors Quick Fixes Over Major Upgrades," The Seattle Times, September 23, 2017, https://www.seattletimes.com/ seattle-news/inslees-quake-group-favors-quick-fixes-over-major-upgrades/.

43. The following 2014 article found that Panarchy: Understanding Transformations in Human and Natural Systems by Lance H. Gunderson (2002) has been cited more than 2,600 times in merely one decade: Craig R. Allen, David G. Angeler, Ahjond S. Garmestani, Lance H. Gunderson, and C.S. Holling, "Panarchy: Theory and Application," Ecosystems 17 (January 2014): 580, https://doi.org/10.1007/s10021-013-9744-2.

44. Keller Easterling, "Action is the Form," in Sentient City: Ubiquitous Computing, Architecture and the Future of Urban Space, ed. Mark Shepard (New York and Cambridge MA, USA: Architectural League and MIT Press, 2011).

45. Mark Wigley, "Space in Crisis," in (C-Lab) for Volume and Urban China Bootleg Edition, 2009, http://c-lab.columbia.edu/0158.html.

46. Wigley, "Space in Crisis." 


\section{Acknowledgements}

This essay was expanded from the author's Final Thesis at the Harvard University Graduate School of Design, presented in December 2016 and completed under the supervision of Associate Professor Jill Desimini. This essay also benefitted from comments by Christa Min and Angela Enman.

\section{Credits}

All figures provided by the Author.

Arthur Tai-Ming Leung is a designer and researcher whose work is situated at the intersection of architecture, urbanism and landscape. His current work focuses on resilient design in urban contexts at risk of natural hazards. He is also the founder of the Next Big One Lab, a design research lab that investigates this topic. Leung received his BEnD (Hon) and MArch from the University of British Columbia, and his MDes from the Harvard University Graduate School of Design. Leung is currently based in Vancouver, Canada. E-mail: mail@arthurleung.ca 